\title{
EVALUATION OF DISTANCE EDUCATION PROCESS IN SPORTS HIGHER EDUCATION
}

\author{
Uğur Özer \\ Hitit University, Turkey \\ E-mail: ugurozer84@hotmail.com
}

\begin{abstract}
In present conditions, where distance education applications in higher education have become widespread due to the Covid-19 pandemic, it is seen in the research studies that the satisfaction levels of the lecturers and students are low. Although the developments in information technologies have reached advanced dimensions, the problems experienced in distance education systems have negatively affected the course functioning of the educators and the students' level of participation in the course. The issues experienced led the researchers to studies in which in-depth analysis of distance education applications was carried out. This study aims to evaluate the distance education applications in sports higher education. This research follows a case-study design, with a qualitative study model applied in terms of the techniques used to analyse the data obtained. The descriptive analysis method was taken as the basis of the study. As a qualitative research tool in the study, a semi-structured interview form was used by choosing the interview technique. The research study group consisted of fourteen academicians working in universities in Turkey, selected by criterion sampling, one of the purposeful sampling methods. The data obtained from the interviews were analysed in the MAXQDA 20 qualitative data analysis program. As a result of the study, it was emphasized that distance education in sports sciences should be designed and implemented according to the targeted outputs of the field-specific courses and the students' accessibility to distance education.
\end{abstract}

Keywords: distance education, sports higher education, case study, MAXQDA

\section{Introduction}

Today, distance education applications emerge as a rapidly growing sector worldwide. Distance education is now an accepted part of general education (Raymond, 2005). Especially with the unprecedented outbreak of the COVID-19 pandemic, distance education applications in higher education have come to the fore worldwide (Hiep-Hung \& Tien-Thi-Hanh, 2020). Although the developments in information technologies have reached advanced dimensions since the first distance education applications were carried out, the effectiveness and efficiency of this education model are questioned in the research studies.

Caleb Phillips announced the first known distance education application in history in the Boston Newspaper on March 20, 1728. In the advertisement, Caleb Phillips stated that he could teach this art to those living in any part of the country who want to learn shorthand, as he would teach someone living in his city (Holmberg, 2008). However, it is not known precisely how this training took place. Nearly a hundred years later, we find more conclusive evidence of distance education. Lund's Weckoblad No. 1833, published weekly in the Swedish city of Lund. In 30, an advertiser offered training by mail to those wishing to work on composition (Holmberg, 2008). In 1840, Isaac Pitman received permission to teach shorthair by mail in the newly established England (Simonson et al., 2015). It will not be difficult to understand how difficult it was to realize open and distance education with the postal service at that time compared to today. 
Uğur ÖZER. Evaluation of distance education process in sports higher education

PROBLEMS

OF EDUCATION

IN THE $21^{\text {st }}$ CENTURY

Vol. 80, No. 1, 2022

196

Distance education, which started its adventure with learning by correspondence, developed over time and gained a different dimension. Researchers and practitioners interested in distance education, telephone, radio, television, computer, internet, etc. they reasoned about how to use all new communication tools to increase the quality of distance education. As a result, they put forward the types, definitions, and theories of distance education (Y1lmaz \& Karataş, 2020).

Distance education is a teaching model in which teaching and learning are carried out separately from each other. Communication between teacher and student is provided through print, electronic, mechanical, or other devices, including applications to be carried out in faceto-face education (Moore, 1973).

According to Wedemeyer (1981), who studied non-traditional learning methods, distance education describes learning activities where the learner and the teacher are physically far from each other. Besides these definitions, the key elements of distance education can be listed as follows (Y1lmaz \& Karataş, 2020):

- What makes distance education different from face-to-face education is the physical separation of the lecturer and the student.

- $\quad$ The point separating distance education from self-studying is that the education is carried out through an institution.

- Technical tools are often used to bring together the educator and the student and deliver the educational content to the student.

- Two-way communication is provided so that the student can benefit from and even initiate the dialogue.

- There is the opportunity to meet when necessary for both didactic and social purposes.

Based on the definitions, trainer, student, and distance education technology can be counted as the essential elements of distance education. The main thing here is that the lecturer and the student are in different places, and distance education occurs through an educational institution. Information technologies, computer hardware systems, and communication tools support education professionals in distance education (Shih et al., 2007).

Distance education nowadays almost entirely refers to online learning, in which teachers and students can be located anywhere, and the learning process can be synchronous or asynchronous. Not simply distant learning, but learning itself, is transformed by the digital age (Altany, 2009).

Today, with the developments in information and communication technologies, time and space limits in education have disappeared, and distance education service has become widespread throughout the world (Ferruci et al., 2009, Kirık, 2014). The aim of the developing and widespread distance education; is to provide education and training opportunities to people with systems that can keep up with the developing technology and contribute to human education without being affected by time and space by removing the time and geographical barriers that disrupt education (Özbay, 2015). Today senior executives across the industry are increasingly seeing online and blended learning as crucial to their long-term strategy, and indeed their survival (Naidu, 2021). With vast global consequences, distance education has taken on new life and significance. Given the global epidemic and the accompanying radical and thorough adjustments to online education, it appears that distance learning will only continue to grow (Mellieon \& Robinson, 2021). Therefore, research in this field will contribute to the formation of universal distance education applications and support the use of technology most effectively and efficiently. In this respect, it is expected that this research will contribute to distance education literature. The study focused on the following questions:

1. What are the thoughts of the lecturers about the distance education practices in sports higher education during the pandemic process? 
2. What are the advantages and disadvantages of distance education applications in sports higher education during the pandemic process?

3. What are the challenges of distance education applications in sports higher education during the pandemic process?

4. What are the views of the lecturers on the management of the education system during the pandemic process?

5. What are the factors affecting distance education?

\section{Research Problem and Research Aim}

The Covid-19 pandemic, which emerged at the end of 2019, affected the whole world in a short time and became the beginning of a complete change in people's lifestyles, priorities, and perspectives on life. This beginning made it necessary for many institutions and sectors to renew themselves (Doğan \& Zorkol, 2021).

One of the areas most affected by the Covid-19 pandemic has been the education sector. In this process, it was aimed to ensure the continuation of education without interruption for all countries where the pandemic was seen (Can, 2020), and it accepted that the best method to prevent contagion in the field of education is distance education applications (Yamamoto \& Altun, 2020). With the transition to distance education, educational institutions that lacked a ready infrastructure experienced various difficulties and negativities. There are two primary aims of this study: 1 . To evaluate the distance education applications that have been put into practice with the Covid-19 pandemic in higher education institutions providing sports education in Turkey. 2. To offer suggestions for the development of distance education applications.

\section{Research Methodology}

\section{Research Model}

The descriptive analysis approach was utilized as the basis for this case study, which used a qualitative study model in terms of the tools used to examine the data acquired. According to the descriptive analysis approach, the information gathered is compiled and evaluated based on the previously established topics. The data can be sorted into themes based on the study questions. It might be presented by thinking about the questions or dimensions asked during the interview and observation phases. Direct quotations are regularly used in descriptive analysis to reflect the viewpoints of the individuals interviewed or observed. This type of analysis aims to deliver the findings to the reader logically and understandably. The data obtained for this purpose are first described systematically and explicitly. These descriptions are explained and evaluated, cause-and-effect correlations are investigated, and conclusions are drawn (Yildırım \& Şimşek, 2016). The planning, design, data collection, analysis, and interpretation of the research were carried out between December 2020 and November 2021.

\section{Ethical Considerations}

Before asking the opinions of the participants, the purpose, structure and duration of the research were stated. In addition, it was stated that participation in the research was completely voluntary, that they could refuse to participate in the study, that their opinions would be used for purely scientific purposes, and their identity information would be kept completely confidential, and voluntary participation consent was requested. 
Uğur ÖZER. Evaluation of distance education process in sports higher education

PROBLEMS

OF EDUCATION

IN THE $21^{\text {st }}$ CENTURY Vol. 80, No. 1,2022

198

\section{Participants}

The research study group consisted of lecturers from the sports field, who were selected by criterion sampling, one of the purposeful sampling methods. The basic understanding in the criterion sampling method is to study the situations that meet a set of predetermined criteria (Yıldırım \& Şimşek, 2016). The research sample was determined by the criterion of teaching over distance education systems in sports sciences. Accordingly, 14 lecturers who met the research criteria could be reached and their opinions.

Table 1

Data on Participants

\begin{tabular}{|c|c|c|c|c|c|}
\hline Participants & Age & Gender & Title & Department & University \\
\hline P1 & 35 & Male & $\begin{array}{l}\text { Assistant } \\
\text { Prof. }\end{array}$ & $\begin{array}{l}\text { Physical Education and } \\
\text { Sports Teaching }\end{array}$ & Erzincan Binali Yıldırım \\
\hline P2 & 30 & Female & Lecturer & Sports Management & Hitit \\
\hline P3 & 34 & Female & Assoc. Prof. & Coaching Education & Gazi \\
\hline P4 & 29 & Female & Lecturer & $\begin{array}{l}\text { Physical Education and } \\
\text { Sports Teaching }\end{array}$ & Hitit \\
\hline P5 & 33 & Male & Lecturer & Sports Management & Hitit \\
\hline P6 & 37 & Female & $\begin{array}{l}\text { Assistant } \\
\text { Prof. }\end{array}$ & Coaching Education & Atatürk \\
\hline P7 & 35 & Female & Assoc. Prof. & Recreation & Kırıkkale \\
\hline P8 & 37 & Male & $\begin{array}{l}\text { Assistant } \\
\text { Prof. }\end{array}$ & Sports Management & Tokat Gaziosmanpaşa \\
\hline P9 & 43 & Male & Lecturer & Coaching Education & Yozgat Bozok \\
\hline P10 & 39 & Male & Lecturer & Coaching Education & Ankara \\
\hline P11 & 34 & Male & Lecturer & Coaching Education & Hitit \\
\hline P12 & 37 & Male & $\begin{array}{l}\text { Assistant } \\
\text { Prof. }\end{array}$ & Sports Management & Hitit \\
\hline P13 & 39 & Male & Lecturer & Sports Management & Artvin Coruh \\
\hline P14 & 37 & Male & Lecturer & Sports Management & Artvin Coruh \\
\hline
\end{tabular}

Table 1 shows the departments where the lecturers interviewed within the scope of the research work in Turkey. According to these data, six interviewees from the sports management department, five from the coaching education department, two from the physical education teaching department, and one from the recreation department were interviewed. Universities where the participants work; Hitit University (5), Artvin Coruh University (2), Gazi University (1), Ankara University (1), Atatürk University (1), Erzincan Binali Y1ldırım University (1), Yozgat Bozok University (1), Tokat Gaziosmanpaşa University (1), Kırıkkale University (1). 


\section{Data Collection and Analysis}

In the study, since it is the shortest way (Yurdakul, 2013) to learn individuals' knowledge, thoughts, attitudes, and behaviours on various subjects and their possible causes, the interview technique was preferred as a qualitative research tool and a semi-structured interview form was used. While preparing the semi-structured interview form used within the scope of the study, the following stages were passed:

- A literature review related to the study area was done.

- Within the framework of the conceptual information obtained from the literature review, questions were formed for the study.

- The questions created were submitted to examine two academicians, who are experts on the research subject, and their opinions were taken.

- Interviews were held on the internet with the interview form containing the following questions, giving their final shape.

1. What is your general opinion about distance education?

2. What are the advantages of distance education over face-to-face education, in your opinion?

3. What are the disadvantages of distance education over face-to-face education, in your opinion?

4. What are the challenges you face when it comes to distance learning?

5. What are your thoughts on the management of the education system in the current period?

\section{Data Analysis}

Two experts analysed the data obtained from the interviews with the participants in the field with the descriptive analysis method. The descriptive analysis process, which was carried out using the MAXQDA 20 qualitative data analysis program, consisted of the following stages (Yıldırım \& Şimşek, 2016):

- Creating a framework for descriptive analysis,

- Data processing following the theme framework,

- Findings identification,

- Findings interpretation.

Similar codes obtained as a result of the descriptive analysis made by the coders were determined as agreements, and different codes were determined as disagreement. The reliability calculation of the findings obtained due to the descriptive analysis was $82 \%$ with the formula "reliability = number of agreements / total number of agreements + disagreements x 100" suggested by Miles and Huberman (1994). According to Miles and Huberman (1994), rates above $70 \%$ are considered reliable.

\section{Research Results}

When Figure 1 is examined, as a result of the analysis of the data obtained in line with the opinions of the lecturers, 4 themes were created. 
Uğur ÖZER. Evaluation of distance education process in sports higher education

PROBLEMS

OF EDUCATION

IN THE $21^{\text {st }}$ CENTURY

Vol. 80, No. 1,2022

200

Figure 1

Themes and Sub-themes Related to the Process of Distance Education

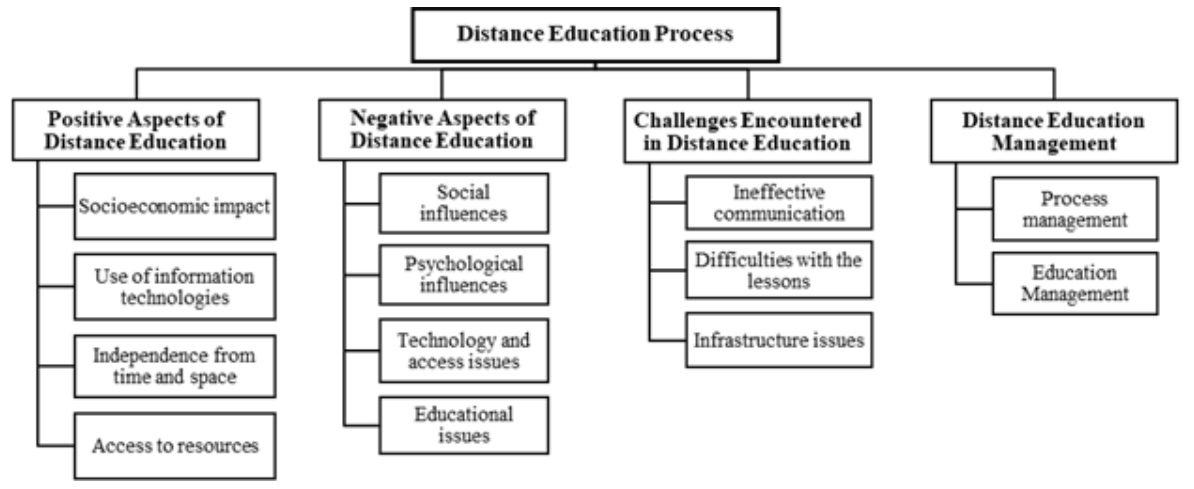

These themes were: 'Positive aspects of distance education', 'Negative aspects of distance education', 'Challenges encountered in distance education', and 'Distance education management', and 13 sub-themes depending on these themes.

Table 2

Data on the Theme of Positive Aspects of Distance Education

\begin{tabular}{|c|c|c|}
\hline Sub-theme & Codes & Example Expressions \\
\hline \multirow[t]{2}{*}{$\begin{array}{l}\text { Socioeconomic } \\
\text { impact } \\
(f=5,13.89 \%)\end{array}$} & $\begin{array}{l}\text { Reducing the } \\
\text { spread of the } \\
\text { pandemic } \\
(f=2,5.56 \%)\end{array}$ & $\begin{array}{l}\text { "In my opinion, the only positive side of distance education compared to formal } \\
\text { education is its contribution to preventing the spread of the worldwide epidemic } \\
\text { we are in." (P11) }\end{array}$ \\
\hline & $\begin{array}{l}\text { Economic } \\
(f=3,8.33 \%)\end{array}$ & $\begin{array}{l}\text { "With the participation of the students from their own homes, they go to their } \\
\text { schools in different cities and provide accommodation, food, transportation, etc. } \\
\text { contributes to their economy by preventing them from making expenses." (P12) }\end{array}$ \\
\hline \multirow{2}{*}{$\begin{array}{l}\text { Use of } \\
\text { information } \\
\text { technologies } \\
(f=7,19.44 \%)\end{array}$} & $\begin{array}{l}\text { Instructional } \\
\text { diversity }(f=3 \\
8.33 \%)\end{array}$ & $\begin{array}{l}\text { "With different teaching methods that can be used in distance education, students' } \\
\text { commitment to the curriculum can be increased." (P14) }\end{array}$ \\
\hline & $\begin{array}{l}\text { Technological } \\
\text { possibilities } \\
(f=4,11.11 \%)\end{array}$ & $\begin{array}{l}\text { "... On the other hand, I think it is positive in terms of encouraging students and } \\
\text { teachers to use technology in lessons." (P10) } \\
\text { "In fact, I think it is a positive process for both educators and students to learn } \\
\text { information Technologies." (P13) }\end{array}$ \\
\hline \multirow{2}{*}{$\begin{array}{l}\text { Independence } \\
\text { from time and } \\
\text { space } \\
(f=13,36.11 \%)\end{array}$} & $\begin{array}{l}\text { No time limit } \\
(f=7,19.44 \%)\end{array}$ & $\begin{array}{l}\text { "It allows } 24 / 7 \text { access to the educational environment of students from any location } \\
\text { with internet connectivity, regardless of time or location." (P2) } \\
\text { "...another benefit is that it provides flexibility in course hours." (P5) }\end{array}$ \\
\hline & $\begin{array}{l}\text { No space limit } \\
(f=6,16.67 \%)\end{array}$ & $\begin{array}{l}\text { "...In addition, I think it is useful for the student to reach from anywhere." (P9) } \\
\text { "The fact that all participants can attend the classes from wherever they want is an } \\
\text { important advantage in terms of money, time and comfort." (P10) }\end{array}$ \\
\hline \multirow[t]{3}{*}{$\begin{array}{l}\text { Access to } \\
\text { resources } \\
(f=11,30.56 \%)\end{array}$} & $\begin{array}{l}\text { Lesson } \\
\text { repetition } \\
(f=6,16.67 \%)\end{array}$ & $\begin{array}{l}\text { "The ability of students to manage their own productivity levels thanks to fast } \\
\text { access to online resources, easy sharing and course repetitions." (P3) } \\
\text { "...if the lectures are recorded as videos and shared with the students, they can be } \\
\text { watched over and over again." (P5) }\end{array}$ \\
\hline & $\begin{array}{l}\text { Source diversity } \\
(f=3,8.33 \%)\end{array}$ & $\begin{array}{l}\text { "I was able to use various educational materials more effectively (videos, YouTube, } \\
\text { congresses, seminars). It is very nice to be able to use many different materials on } \\
\text { technical and theoretical subjects." (P7) }\end{array}$ \\
\hline & $\begin{array}{l}\text { Access to } \\
\text { information }(f=2 \text {, } \\
5.56 \%)\end{array}$ & $\begin{array}{l}\text { "...Possibility of teaching lessons with technological tools and the possibility of } \\
\text { accessing information quickly and easily constitute its positive aspects." (P6) }\end{array}$ \\
\hline
\end{tabular}


Table 2 shows four sub-themes and nine codes related to the theme of 'Positive aspects of distance education'. The codes were created according to 36 different views. According to these data, the sub-theme 'Socioeconomic impact' $(f=5)$ constituted $13.89 \%$ of the total opinions $(f=36)$, the sub-theme 'Use of information technologies' $(f=7)$ constituted $19.44 \%$ of the total opinions $(f=36)$, The 'Independence from time and place' sub-theme $(f=13)$ constitutes $36.11 \%$ of the total opinions $(f=36)$, and the 'Access to resources' sub-theme $(f=11)$ constitutes $30.56 \%$ of the total opinions $(f=36)$. The "No time limit" has the highest rate $(f=7)$ among the codes, with $19.44 \%$. Accordingly, both students and educators have a wider time interval for teaching than face-to-face education. In addition, it was emphasized that students and educators could attend classes from places they are outside of school, with the code "No space limit" $(f=6,16.67 \%)$. The "Lesson repetition" code $(f=6,16.67 \%)$ means that students can repeat the courses taught and recorded in the system whenever they wish. In other codes created, it was emphasized that the positive effects of technology on education processes, students can easily access various educational resources and information in digital environments, the distance education process is more economical for students than face-to-face education, and the process is important in terms of reducing the spread of the pandemic. 
Uğur ÖZER. Evaluation of distance education process in sports higher education

PROBLEMS

OF EDUCATION

IN THE $21^{\text {st }}$ CENTURY Vol. 80 , No. 1,2022

202

Table 3

Data on the Theme of Negative Aspects of Distance Education

\begin{tabular}{|c|c|c|}
\hline Sub-theme & Codes & Example Expressions \\
\hline \multirow{4}{*}{$\begin{array}{l}\text { Social } \\
\text { influences } \\
(f=18,29.52 \%)\end{array}$} & $\begin{array}{l}\text { Socialization } \\
(f=2,3.28 \%)\end{array}$ & $\begin{array}{l}\text { "Students cannot get the chance to socialize by staying away from the classroom } \\
\text { and friend environment." (P12) }\end{array}$ \\
\hline & $\begin{array}{l}\text { Inequality of } \\
\text { opportunity } \\
(f=4,6.56 \%)\end{array}$ & $\begin{array}{l}\text { I do not think that distance education can be efficient unless equal conditions are } \\
\text { created for every student." (P4) } \\
\text { "Since not every student has the same minimum requirements, the lack of equality } \\
\text { in education is the most important negative aspect of when comparing distance } \\
\text { education to face-to-face education." (P5) }\end{array}$ \\
\hline & $\begin{array}{l}\text { Communication } \\
\text { issues } \\
(f=6,9.84 \%)\end{array}$ & $\begin{array}{l}\text { "In distance education, it is not possible to interact with the student as in face-to- } \\
\text { face education. Questions asked often go unanswered." (P12) } \\
\text { "The lack of direct interaction between the student and the teacher, the } \\
\text { communication problem..." (P6) }\end{array}$ \\
\hline & $\begin{array}{l}\text { Participation } \\
\text { issues } \\
(f=6,9.84 \%)\end{array}$ & $\begin{array}{l}\text { "Not all students can attend the class at the designated time." (P14) } \\
\text { "It is very difficult to ensure that the student participates in the lesson online." (P5) }\end{array}$ \\
\hline \multirow[t]{3}{*}{$\begin{array}{l}\text { Psychological } \\
\text { influences } \\
(f=15,24.59 \%)\end{array}$} & $\begin{array}{l}\text { Motivation } \\
\text { issues } \\
(f=10,16.39 \%)\end{array}$ & $\begin{array}{l}\text { "Students have motivation problems ..." (P8) } \\
\text { "The biggest challenge of this process has been the adaptation problem." (P9) }\end{array}$ \\
\hline & $\begin{array}{l}\text { Educator } \\
\text { indifference } \\
(f=2,3.28 \%)\end{array}$ & $\begin{array}{l}\text { "Some of our colleagues have caused the student's interest in the lesson to } \\
\text { decrease." (P6) }\end{array}$ \\
\hline & $\begin{array}{l}\text { Student apathy } \\
(f=3,4.92 \%)\end{array}$ & $\begin{array}{l}\text { "The presence of educators and students who do not care about the process } \\
\text { creates a different negative situation ..." (P13) }\end{array}$ \\
\hline \multirow{2}{*}{$\begin{array}{l}\text { Technology } \\
\text { and access } \\
\text { issues } \\
(f=13,21.31 \%)\end{array}$} & $\begin{array}{l}\text { Lack of } \\
\text { equipment } \\
(f=5,8.2 \%)\end{array}$ & $\begin{array}{l}\text { "Another problem is that students do not have the necessary tools to participate in } \\
\text { the lesson ..." (P4) }\end{array}$ \\
\hline & $\begin{array}{l}\text { Access issues } \\
(f=8,13.11 \%)\end{array}$ & $\begin{array}{l}\text { "Access to education was disrupted for students with insufficient internet } \\
\text { infrastructure." (P6) } \\
\text { "...access to classes is a big problem for both us and students." (G2) }\end{array}$ \\
\hline \multirow[t]{4}{*}{$\begin{array}{l}\text { Educational } \\
\text { issues } \\
(f=15,24.59 \%)\end{array}$} & $\begin{array}{l}\text { Ineffective } \\
\text { training } \\
(f=2,3.28 \%)\end{array}$ & $\begin{array}{l}\text { "I believe that the student's active engagement in the class is not being realized. } \\
\text { In addition, although the lecturer can reach the student at the teaching point, he } \\
\text { cannot reach the student at the training point." (P10) }\end{array}$ \\
\hline & $\begin{array}{l}\text { Exam abuse } \\
(f=2,3.28 \%)\end{array}$ & $\begin{array}{l}\text { "...The fact that students cheat during the process and this situation cannot be } \\
\text { prevented creates negativity." (P13) }\end{array}$ \\
\hline & $\begin{array}{l}\text { Theoretical } \\
\text { lessons } \\
(f=2,3.28 \%)\end{array}$ & $\begin{array}{l}\text { "Although theoretical lessons are given with synchronous training, I think that these } \\
\text { are not efficient enough." (P12) }\end{array}$ \\
\hline & $\begin{array}{l}\text { Applied lessons } \\
(f=9,14.75 \%)\end{array}$ & $\begin{array}{l}\text { "The system is not suitable for providing sufficient education for the field of sports } \\
\text { sciences... Necessary opportunities for practice courses are not provided." (P8) } \\
\text { "The most important problem is inability to conduct practical lessons." (P12) }\end{array}$ \\
\hline
\end{tabular}

Table 3 shows four sub-themes and 13 codes related to the "Negative aspects of distance education" theme. The codes were created according to 61 different views. According to these data, the "Social influences" sub-theme $(f=18)$ constituted $29.52 \%$ of the total opinions $(f=61)$, the "Psychological influences" sub-theme $(f=15)$ constituted $24.59 \%$ of the total opinions $(f=61)$, "Technology and access issues" sub-theme $(f=13)$ constitutes $21.31 \%$ of the total opinions $(f=61)$, and the "Educational issues" sub-theme $(f=15)$ constitutes $24.59 \%$ of the total opinions $(f=61)$. The "Motivation issues" code has the highest rate $(f=10)$ with $16.39 \%$ among 
the codes. Accordingly, the motivation problem experienced by educators and students in the Vol. 80 , No. 1,2022 distance education process was emphasized. "Applied lessons" code $(f=9,14.75)$ has been a frequently expressed code because applied sports lessons cannot be processed properly in the distance education process. "Access issues" code $(f=8,13.11 \%)$ was determined as another code that expresses the problems related to internet access problems experienced by both students and educators. With the "Participation issues" code $(f=6,9.84 \%)$, the educators stated that they sometimes had problems with the participation of the students in the education module. The "Communication issues" code $(f=6,9.84 \%)$ was created based on the statement that the educator and the student could not establish healthy communication during distance education. Another important issue emphasized by the educators is the "Lack of equipment" $(f=5,8.2 \%)$ code, which was created because students stated that they did not have the necessary equipment for distance education. In the other codes created, it was emphasized that there is inequality of opportunity because not every student has the minimum requirements, that some students and educators are indifferent, that even the theoretical lessons cannot be taught efficiently enough, that there may be abuse in the exams by cheating, that the students are kept away from the social education environment and that education cannot be provided effectively.

\section{Table 4}

\section{Data on the Theme of Challenges Encountered in Distance Education}

\begin{tabular}{|c|c|c|}
\hline Sub-theme & Codes & Example Expressions \\
\hline \multirow[t]{2}{*}{$\begin{array}{l}\text { Ineffective } \\
\text { communication } \\
(f=5,16.13 \%)\end{array}$} & $\begin{array}{l}\text { Disinterested } \\
\text { students } \\
(f=2,6.45 \%)\end{array}$ & "Trying to increase student interest in the lesson is the biggest challenge." (P11) \\
\hline & $\begin{array}{l}\text { Miscommunication } \\
(f=3,9.68 \%)\end{array}$ & $\begin{array}{l}\text { "I do not have difficulties in communicating with the student and in reaching the } \\
\text { students ..." (P4) }\end{array}$ \\
\hline \multirow[t]{3}{*}{$\begin{array}{l}\text { Difficulties with } \\
\text { the lessons } \\
(f=10,32.25 \%)\end{array}$} & $\begin{array}{l}\text { Lesson process } \\
(f=2,6.45 \%)\end{array}$ & $\begin{array}{l}\text { "...In this sense, teaching efficiency and teaching diversity of a teacher who tries } \\
\text { to teach the lesson in face-to-face lessons in the form of questions and answers } \\
\text { decreases" (P10) }\end{array}$ \\
\hline & $\begin{array}{l}\text { Lesson intensity } \\
(f=2,6.45 \%)\end{array}$ & $\begin{array}{l}\text { "Because of my intensive classes (15 lessons), I cannot get up from the computer. } \\
\text { It is difficult to make a promise to the student, so it is very tiring to simply talk for } \\
1 \text { hour and } 30 \text { minutes without a break" (P7) }\end{array}$ \\
\hline & $\begin{array}{l}\text { Difficulty in } \\
\text { assessment and } \\
\text { evaluation } \\
(f=6,19.35 \%)\end{array}$ & $\begin{array}{l}\text { "In distance education, it is extremely difficult to properly develop a measuring } \\
\text { and evaluation system." (P5) } \\
\text { "We do not have a good system in terms of assessment and evaluation." (P7) }\end{array}$ \\
\hline \multirow[t]{4}{*}{$\begin{array}{l}\text { Infrastructure } \\
\text { issues } \\
(f=16,51.61 \%)\end{array}$} & $\begin{array}{l}\text { Insufficient } \\
\text { infrastructure } \\
(f=4,12.9 \%)\end{array}$ & $\begin{array}{l}\text { "The problem is that educational institutions do not have the infrastructure to } \\
\text { provide distance education." (P13) }\end{array}$ \\
\hline & $\begin{array}{l}\text { Failure to } \\
\text { meet minimum } \\
\text { requirements } \\
(f=3,9.68 \%)\end{array}$ & $\begin{array}{l}\text { "Failure to meet the minimum requirements for the conduct of the courses is an } \\
\text { important deficiency" (P1) }\end{array}$ \\
\hline & $\begin{array}{l}\text { Connection issues } \\
(f=6,19.35 \%)\end{array}$ & $\begin{array}{l}\text { "Inability to connect to the system caused by the internet infrastructure and } \\
\text { disconnection during the lesson..." (P4) } \\
\text { "First of all, I have internet connection problems because the place where I live } \\
\text { is in the countryside." (P2) }\end{array}$ \\
\hline & $\begin{array}{l}\text { Education platform } \\
\text { issues } \\
(f=3,9.68 \%)\end{array}$ & $\begin{array}{l}\text { "The problem is that the interfaces of distance education systems are not user- } \\
\text { friendly." (P10) }\end{array}$ \\
\hline
\end{tabular}


Uğur ÖZER. Evaluation of distance education process in sports higher education

PROBLEMS

OF EDUCATION

IN THE $21^{\text {st }}$ CENTURY Vol. 80, No. 1,2022

204

Table 4 shows three sub-themes and nine codes related to the theme of "Challenges encountered in distance education". The codes were created according to 31 different views. According to these data, the sub-theme "Ineffective communication" $(f=5)$ constituted 16.13\% of the total opinions $(f=31)$, the sub-theme "Difficulties with the lessons" $(f=10)$ constituted $32.25 \%$ of the total opinions $(f=31)$, The sub-theme of "Infrastructure issues" $(f=16)$ constitutes " $51.61 \%$ of the total opinions $(f=31)$. "Connection issues" and "Difficulty in assessment and evaluation" $(f=6,19.35 \%)$ codes have the highest rate among the codes. While the "Connection issues" code indicates connection problems originating from the internet infrastructure, the "Difficulty in assessment and evaluation" code refers to the difficulties associated with students' exam practices and their assessment and grading. With the code "insufficient infrastructure", it was stated that sufficient infrastructure for distance education could not be fully established in educational institutions. In the other codes created, it was emphasized that the minimum requirements for the conduct of the courses were not met, the problems related to the use of distance education modules, the difficulty in communicating with the students, the ineffectiveness of the courses, the complaints of some educators about the intensity of the courses, and the indifference of the students to the courses.

Table 5

Data on the Theme of Distance Education Management

\begin{tabular}{|c|c|c|}
\hline Sub-theme & Codes & Example Expressions \\
\hline \multirow[t]{5}{*}{$\begin{array}{l}\text { Process } \\
\text { management } \\
(f=24, \\
66.67 \%)\end{array}$} & $\begin{array}{l}\text { Distance education } \\
\text { process } \\
(f=11,30.56 \%)\end{array}$ & $\begin{array}{l}\text { "Distance education is a practical training opportunity for situations where } \\
\text { people's educational institutions must be closed, such as global diseases or } \\
\text { natural disasters" (P14) } \\
\text { "In general, I think we failed in the distance education process." (P4) } \\
\text { "The conditions we are in have necessitated the distance education process." } \\
\text { (P5) }\end{array}$ \\
\hline & $\begin{array}{l}\text { Management } \\
\text { follow-up } \\
(f=2,5.56 \%)\end{array}$ & $\begin{array}{l}\text { "I don't find it ethical that the top management should interfere in the lessons so } \\
\text { much and that the lecturers should prepare reports on what they are doing." (P1) }\end{array}$ \\
\hline & $\begin{array}{l}\text { In-service training } \\
(f=3,8.33 \%)\end{array}$ & $\begin{array}{l}\text { "The biggest shortcoming of our university in this process is that it does not } \\
\text { adequately train academics..." (P11) }\end{array}$ \\
\hline & $\begin{array}{l}\text { Process applications } \\
(f=5,13.89 \%)\end{array}$ & $\begin{array}{l}\text { "I believe that the process of online education is poorly managed. In this } \\
\text { process, the Council of Higher Education avoided taking responsibility and left } \\
\text { the decisions to the universities, universities waited for the departments and } \\
\text { departments for the teachers to make decisions. As a result, no decision could } \\
\text { be taken properly, and unity could not be achieved." (P12) } \\
\text { "Although there are problems in terms of process applications, I think that } \\
\text { distance education is necessary in the current situation." (P10) }\end{array}$ \\
\hline & $\begin{array}{l}\text { Crisis management } \\
(f=3,8.33 \%)\end{array}$ & $\begin{array}{l}\text { "In my opinion, it was a complete crisis process and both the pre-crisis period, } \\
\text { and the ongoing practices reveal that the crisis process was not managed } \\
\text { properly." (P13) }\end{array}$ \\
\hline \multirow{3}{*}{$\begin{array}{l}\text { Education } \\
\text { management } \\
(f=12, \\
33.33 \%)\end{array}$} & $\begin{array}{l}\text { Synchronous } \\
\text { training } \\
(f=3,8.33 \%)\end{array}$ & $\begin{array}{l}\text { "Synchronous training is healthier than asynchronous training. Because you can } \\
\text { get instant feedback." (P1) }\end{array}$ \\
\hline & $\begin{array}{l}\text { Education system } \\
(f=2,5.56 \%)\end{array}$ & $\begin{array}{l}\text { "In my opinion, our education system is wasting our time imagining that with } \\
\text { a magic wand this epidemic will end, and we will go back to the old days as if } \\
\text { nothing had happened." (P13) }\end{array}$ \\
\hline & $\begin{array}{l}\text { Education platform } \\
(f=7,19.44 \%)\end{array}$ & $\begin{array}{l}\text { "It is an important indicator for the next process that especially higher education } \\
\text { institutions increase their distance education infrastructure to a certain level in a } \\
\text { short time." (P10) } \\
\text { "Distance education platforms have technical inadequacies. I think it will get } \\
\text { better over time." (P6) }\end{array}$ \\
\hline
\end{tabular}


Table 5 shows two sub-themes and eight codes related to the "Distance education management" theme. The codes were created according to 36 different views. According to these data, the "Process Management" sub-theme $(f=24)$ constitutes $66.67 \%$ of the total opinions $(f=31)$, and the "Education management" sub-theme $(f=12)$ constitutes $33.33 \%$ of the total opinions $(f=31)$. The code "Distance education process" $(f=11,30.56 \%)$ has the highest rate. The "distance education process" code was created based on the statements that students generally evaluate the distance education process. The "Education platform" code $(f=7,19.44 \%)$ includes the opinions about the education platforms used by the universities in the distance education process. In the other codes created, there are expressions related to synchronous education, crisis process and management, in-service training, administrators' control and intervention authority over the teaching staff, and education systems in general.

\section{Discussion}

The education process consists of students, lecturers, courses, methods, and learning environments (Bacanl1, 2021). On the other hand, the learning environment is considered the physical characteristics of the environment where learning occurs and all kinds of environmental factors that affect learning (Sahranç, 2019b). The student is at the centre of the education process (Sahranç, 2019a), and there are factors that positively or negatively affect the student's education, making it easier or harder to learn. These are factors related to the student, the teaching method, the learning material, the learning environment, and the educator (Yeşilyaprak, 2020). All of these factors will be decisive in achieving the goals of the education applied.

With distance education, a flexible, rich, and interactive education environment can be created apart from the stereotyped structure of traditional education. At the same time, many factors such as buildings, classrooms, and educational materials that limit the capacity of students to participate in education are prevented, thereby reducing the cost of education. From this point of view, the importance of distance education cannot be ignored (Özbay, 2015).

In the study, according to participant opinions, the positive aspects of distance education were determined as the absence of time and space limits, technological opportunities and course repetition, variety of teaching and resources, ease of access to information, economy, and reducing the spread of pandemics.

In line with the research conducted by Özdoğan and Berkant (2020) on school administrators, teachers, and students, the advantages of distance education can be made more often than face-to-face education regardless of time and place, the lessons can be watched many times, the training needs can be met within certain restrictions, it provides protection against the transmission of the disease, and the awareness of the importance of technology in education increases. They listed them as developing technological skills and facilitating learning.

In the study conducted by Dolmaci and Dolmac1 (2020), in which lecturers' views on distance education were determined, it was stated that distance education has opportunities such as providing time-space flexibility, facilitating access to resources, preventing classroom pressure, and preventing discipline problems. In the study conducted by Cejas Martinez et al. (2021), it was stated as the positive aspect of distance education that there is no time and place limit in the learning-teaching process.

Serçemeli and Kurnaz (2020) on undergraduate students, the opportunity to rewatch video recordings, the flexibility of education options, and the time savings are all cited as advantages of distance education.

In Alpaslan's (2020) study on the views of faculty members on the use of distance education, the opinions in the category of advantages of distance education are; distance education is practical, flexible, independent of time and place, creating an alternative education 
Uğur ÖZER. Evaluation of distance education process in sports higher education

PROBLEMS

OF EDUCATION

IN THE $21^{\text {st }}$ CENTURY Vol. 80, No. 1,2022

206

environment, enriching the educational environment, easily adapting to new situations, providing equality in access to information, directing the use of computers to a good field and enabling students to take lessons from different teachers.

Markovič Krstić and Miloševič Radulović (2021) evaluated the distance education process in Serbia in their study. According to the results of the study, they stated that distance education provides flexibility as students and teachers can determine the place, time and pace of learning themselves, increases the effectiveness of education, encourages students' creativity, and more effective learning occurs in a short time.

In the study conducted by Uluöz (2020) on sports science students, ease of access for students with disabilities, protection of health, opportunities provided by the university administration, the chance to watch the course again, exam advantage, and encouraging research are positive opinions about distance education.

When the relevant literature is examined, it is seen that similar results regarding the positive aspects of distance education have been reached in the studies.

Considering the contagious effect of the Covid 19 pandemic, the transition to quarantine measures and distance education has also caused negativities in the Turkish education system, leading to the formation of education inadequacy. Lack of education can be social, political, economic, etc. It can be defined as the inability of education to be carried out, planned, and presented correctly for various reasons (Köroğlu, 2021). Distance education practices are also one of the practical reasons for the emergence of negativities that cause education inadequacy.

In the study, the participants' most emphasized negativities towards distance education were identified as communication problems, problems in accessing and participating in classes, motivation problems, ineffective teaching of applied lessons, and inequality of opportunity. These problems prevent the effective execution of the lessons and make it difficult to realize the essential functions of education. When the relevant literature is examined, it has been determined that the studies conducted have obtained results in parallel with the study's findings.

In the study conducted by Yolcu (2020) on prospective classroom teachers, it was concluded that the technical equipment of the students is insufficient, they do not have the opportunity to ask questions during distance education, their communication with educators and their friends is incomplete, and distance education is not suitable for practical lessons. According to Şişman (2020), the individual learns in various ways (listening, reading, seeing, speaking, doing some work). In these learning activities, there is an order from the most passive to the most active. As the activity increases, the learning power and effectiveness also increase. Active participation, where several of these are used, is significant as it affects attention, perception, and motivational factors. The individual's attention, perception, and motivation who learns something by doing can be carried to the highest possible level. Educational efficiency decreases as distance education in departments where applied courses are intense and learning cannot be realized. In the study conducted by Gorghiu et al. (2021), it was concluded that students have a lower perception of the usefulness of distance education due to the inability to carry out applied courses and laboratory studies.

In the study conducted by Doğan and Zorkol (2021) on teachers affiliated with the Ministry of National Education (MEB), the lack of eye contact and emotion transfer in distance education and difficulties in feedback and communication with students was expressed as disadvantages. According to the answers obtained from the students' opinions in Türküresin's (2020) study, the most damaging element regarding the distance education system is the lack of interaction.

In the studies of Serçemeli and Kurnaz (2020), issues such as not accessing the Internet and the lecturer and feeling socially isolated were identified as the negative aspects of distance education. 
In the study of Özdoğan and Berkant (2020), the disadvantages of distance education are listed as follows; Inadequate measurement and evaluation, loss of motivation, lack of Internet and computers, inequality of opportunity, lack of interaction, technical problems, lack of socialization and being caught unprepared for the process.

Avcr and Akdeniz (2021), in their study on the problems faced by MEB teachers regarding the distance education process, emphasized that teachers often have issues with technological infrastructure and the Internet, and students' connection problems and their inability to attend live classes cause inequality of opportunity in education. Lautenbach and Randell (2020) stated that one of the most critical problems is that students who do not have internet access cannot participate in distance education.

In the study, the difficulties experienced by the lecturers in the distance education process were also tried to be determined. Accordingly, the participants stated that they had difficulties in communicating with students regarding lessons and infrastructure problems. The students' indifference to the lessons in the distance education process, the difficulty in communicating with them, and the ineffective implementation of the assessment and evaluation system prevent the lessons from being taught efficiently. In addition, the fact that the necessary equipment and internet infrastructure for the conduct of the courses are not provided equally to everyone has been identified as another reason that reduces the educational efficiency.

In the study of Dolmac1 and Dolmac1 (2020), it was determined that face-to-face education was found to be more efficient due to its advantages such as being able to deal with students one-on-one, making eye contact, communicating with body language, providing active participation and motivation in the lesson, and ease in assessment and evaluation.

Keskin and Kaya (2020) found that most of the students (84.4\%) did not find web-based distance education as effective as face-to-face education and more than half $(53.9 \%)$ of them had technical problems during their education.

Karakuş et al. (2020) concluded that the most common technical problems experienced by Turkish pre-service teacher candidates in the distance education process are the internet/ connection problems and device/hardware deficiency. According to Manuel et al. (2021), students' most significant challenge is poor internet connection in rural areas. Weak internet signal prevents students from actively participating in distance education.

According to the research conducted by Karadağ and Yücel (2020) on 17,939 undergraduate students, $51 \%$ of the students stated that they were dissatisfied with the lecturers' teaching skills.

According to the results of the research conducted by Karadağ et al. (2021), in which the distance education capacities of universities were examined during the Covid-19 pandemic, distance education offered at universities in Turkey; It has been determined that universities are low and insufficient in terms of human resources, hardware and software infrastructures and capacities, content production capacities, examination infrastructures, and capacities and budgets.

According to the study of Dhurumraj et al. (2020), challenges in remote education include exorbitant data costs, the time it takes to develop presentations, the absence of professional help needed to navigate virtual digital platforms, and technical difficulties with the use of information and communication technology equipment.

In the study, views on the management of the distance education process are also included. According to the participants, although distance education is a practical system that can be applied in mandatory situations, it is stated that the process is not managed correctly. According to the participant's views, the decision-making authorities during the transition to and implementation of the distance education process in Turkey avoided taking responsibility and left the decisions to the universities. On the other hand, universities left the decisions about the process to the departments and departments to the lecturers. As a result, the decisions to be taken

\author{
PROBLEMS \\ OF EDUCATION \\ IN THE $21^{\text {st }}$ CENTURY \\ Vol. 80 , No. 1,2022 \\ 207
}


Uğur ÖZER. Evaluation of distance education process in sports higher education

PROBLEMS

OF EDUCATION

IN THE $21^{\text {st }}$ CENTURY Vol. 80, No. 1,2022

208

were delayed, and the process was disrupted. Apart from this, the administrators' involvement in the teaching of the courses by following the lecturers closely during the distance education process, the problems experienced during the use of synchronous education platforms, and the insufficient training of the lecturers for these platforms revealed the views that the crisis process was not managed effectively enough.

Managers have essential duties in minimizing the adverse effects of distance education. In particular, administrators will have a significant impact on ensuring the motivation of lecturers, students, and parents and ensuring the continuation of educational activities with minimal disruption in this process (Akyavuz \& Çakın, 2020). One of the issues that managers should pay attention to in using distance education platforms is data security because these platforms process both public and private personal data of students and educators. All of these personal data must be handled in line with Law No. 6698 on Personal Data Protection. It is essential to follow the law when recording courses and exams offered through platforms and transferring data to third parties. Otherwise, if required by law, criminal and administrative responsibilities arise (Özçelik, 2021). Higher education today has a variety of learning objectives that require a well-rounded set of educational strategies. Since students' learning needs also vary, offering options to all students has become an important issue (Eastman \& Swift, 2001). Therefore, dividing education into two classes, formal and distance, is a result of thinking with the norms of the past century. There is no room for such artificial divisions in the future. There is a place for both face-to-face and (with different versions) online training in optimally designed training. How to blend these different modes of transmission is complete; it should be left to universities, faculties, departments, and, in the final analysis, to the teaching staff (Erkut, 2020). However, it is necessary to monitor and evaluate educational practices by education administrators and policymakers and correct any deficiencies. Otherwise, the education system implemented with these deficiencies will cause learning losses (Koç, 2021).

Although it is difficult to predict the future, we should not forget that learning is a social and emotional process rather than the assimilation of information. Learning also requires reflecting, evaluating, interpreting, and combining it. Confronting conflicting information, building a cohesive argument, and openly sharing ideas with others are also part of learning. The Internet can help learners in the first step by making information accessible. On the other hand, universities help in other aspects of learning by providing good tutorial models, both online and in-person, by supporting course processes and live learning communities (Kaya, 2019). Online education will continue to develop and become widespread in the coming years. For institutions that want to be at the forefront of education, it would be wise to embrace the opportunities presented by this new teaching and learning paradigm (Eastman \& Swift, 2001)

\section{Conclusions and Implications}

Distance education is an alternative model that can be used in cases where the formal education system is disrupted for any reason. Although the developments in information technologies have reached advanced dimensions, the problems experienced in distance education systems negatively affect the course functioning of the educators and the level of participation of the students in the course. Therefore, it can be said that research studies on distance education are important in order to create a functional education model.

Although the study aimed to evaluate the distance education process in sports sciences, it is seen that the research findings made in different fields are similar. However, the inclusion of applied courses in sports education and the limited conduct of these courses through distance education can be considered another aspect from the areas based on theoretical education. As a result of the distance execution of applied sports lessons, students may experience learning losses and inadequacies. Therefore, distance education in sports sciences should be handled 
with its different dimensions specific to the field. It should be designed and implemented according to the courses' targeted outputs, to applied lessons, and students' accessibility to distance education.

Another critical issue that arises in distance education is data security. The recording of lecturers and students during the lessons, how these records are stored, and who can access the records are issues that need attention in terms of protecting personal data. For the distance education process to be carried out in accordance with individual rights, technical, administrative, and legal measures regarding data security should be carefully carried out by subject experts.

Distance education applied during the Covid 19 process has positives and negatives for lecturers and students. This situation also varies according to the departments. Studies to be carried out for lecturers and students in different departments will contribute to negativities. Therefore, more research is required to determine distance education's efficacy, advantages, and disadvantages.

\section{References}

Akyavuz, E. K., \& Çakın, M. (2020). Covid-19 salgınının eğitime etkisi konusunda okul yöneticilerinin görüşleri [School administrators' views on the effect of Covid-19 pandemic on education]. Turkish Studies, 15(4), 723-737. https://dx.doi.org/10.7827/TurkishStudies.44140

Alpaslan, M. (2020). Öğretim üyelerinin özel yeteneklilerin eğitiminde uzaktan eğitimin kullanımına yönelik görüşleri [Opinions of faculty members on the use of distance education in the education of gifted students]. Açıöğgretim Uygulamaları ve Araştırmaları Dergisi, 6(1), 126147. https://dergipark.org.tr/tr/pub/auad/issue/55639/761315

Altany, A. (2009). Distance learning and the scholarship of teaching and learning. In P. Rogers, G. Berg, J. Boettecher, C. Howard, L. Justice, \& K. Schenk (Eds.), Encyclopedia of distance learning (2nd ed., Vol. 2, pp. 731-735). Information Science Reference.

Avcı, F., \& Akdeniz, E. C. (2021). Koronavirüs (Covid-19) salgını ve uzaktan eğitim sürecinde karşılaşılan sorunlar konusunda öğretmenlerin değerlendirmeleri [Assessment of teachers on the Covid-19 epidemic and problems encountered in distance learning process]. Uluslararast Sosyal Bilimler ve Eğitim Dergisi, 3(4), 117-154. https://dergipark.org.tr/tr/pub/usbed/issue/61198/910183

Bacanl, H. (2021). Eğitim psikolojisi [Education psychology] (27th ed.). Pegem Akademi.

Can, E. (2020). Coronavirüs (Covid-19) pandemisi ve pedagojik yansımaları: Türkiye'de açık ve uzaktan eğitim uygulamaları [Coronavirus (Covid-19) pandemic and its pedagogical reflections: Open and distance education practices in Turkey]. Açıöğretim Uygulamaları ve Araştırmaları Dergisi, 6(2), 11-53. https://dergipark.org.tr/tr/pub/auad/issue/55662/761354

Cejas Martinez, M. F., Navarro Cejas, M., Venegas Alvarez, G. S., Proano Rodriguez, C. E., \& Mendoza Velazco, D. J. (2021). Student perceptions of Ecuadorian virtual platforms during the Covid-19 pandemic. Problems of Education in the 21st Century, 79(2), 241-254. https://doi.org/10.33225/pec/21.79.241

Dhurumraj, T., Ramaila, S., Raban, F., \& Ashruf, A. (2020). Broadening educational pathways to STEM education through online teaching and learning during Covid-19: Teachers' perspectives. Journal of Baltic Science Education, 19(6A), 1055-1067. https://doi.org/10.33225/jbse/20.19.1055

Doğan, S., \& Zorkol, F. (2021). Uzaktan eğitim ve yüz yüze eğitim süreçlerinde sınıf disiplini: Karşılaştırmalı bir olgubilim araştırması [Classroom discipline in distance education and face-toface education processes: A comparative phenomenology study]. In Ş. Koca \& M.Ş. Akgül (Eds.), Ĕ̌itim bilimlerinde araştirma ve değerlendirme I (pp. 15-35). Gece Kitaplığı.

Dolmac1, M., \& Dolmacı, A. (2020). Eş zamanlı uzaktan eğitimle yabancı dil öğretiminde öğretim elemanlarının görüşleri: Bir Covid 19 örneği [The views of lecturers in foreign language teaching via synchronous distance education: A Covid 19 case]. Türk Eğitim Bilimleri Dergisi, 18(2), 706732. https://doi.org/10.37217/tebd.783986

Eastman, J. K., \& Swift, C. O. (2001). New horizons in distance education: The online learner-centered marketing class. Journal of Marketing Education, 23(1), 25-34. https://doi.org/10.1177/0273475301231004 
Uğur ÖZER. Evaluation of distance education process in sports higher education

PROBLEMS

OF EDUCATION IN THE $21^{\text {st }}$ CENTURY Vol. 80, No. 1,2022

210

Erkut, E. (2020). Covid-19 sonrası yükseköğretim [Higher education after Covid-19]. Yükseköğretim Dergisi, 10(2), 125-133. https://doi.org/10.2399/yod.20.002

Ferruci, F., Scanniello, G., \& Tortora, G. (2009). E-world: A platform for the management of adaptive e-learning processes. In M. R. Syed (Ed.), Methods and applications for advancing distance education technologies: International issues and solutions (pp. 9-25). Information Science Reference.

Gorghiu, G., Pribeanu, C., Manea, V. I., Lamanauskas, V., \& Makarskaitè-Petkevičienė, R. (2021). The usefulness of online learning during the Covid19 pandemic as perceived by engineering education students: A multidimensional model. Journal of Baltic Science Education, 20(5), 716-728. https://doi.org/10.33225/jbse/21.20.716

Hiep-Hung P., \& Tien-Thi-Hanh H. (2020) Toward a 'new normal' with e-learning in Vietnamese higher education during the post COVID-19 pandemic. Higher Education Research \& Development, 39(7), 1327-1331. https://doi.org/10.1080/07294360.2020.1823945

Holmberg, B. (2008). The evolution, principles and practices of distance education. Bibliotheksund Informations system der Universitat Oldenburg. https://citeseerx.ist.psu.edu/viewdoc/ download?doi=10.1.1.466.9000\&rep $=$ rep1\&type $=$ pdf

Karadağ, E., Çiftçi, S. K., Gök, R., Su, A., Kocatürk, H. E., \& Çiftçi, Ş. S. (2021). Covid-19 pandemisi sürecince üniversitelerin uzaktan eğitim kapasiteleri [Distance education capacities of universities during the Covid-19 pandemic process]. Üniversite Araştırmaları Dergisi, 4(1), 8-22. https://dergipark.org.tr/tr/pub/uad/issue/60894/874799

Karadağ, E., \& Yücel, C. (2020). Yeni tip koronavirüs pandemisi döneminde üniversitelerde uzaktan eğitim: Lisans öğrencileri kapsamında bir değerlendirme çalışması [Distance education at universities during the novel coronavirus pandemic: An analysis of undergraduate students' perceptions]. Yüksekögretim Dergisi, 10(2), 181-192. https://doi.org/10.2399/yod.20.730688

Karakuş, N., Ucuzsatar, N., Karacaoğlu, M., Esendemir, N., \& Bayraktar, D. (2020). Türkçe öğretmeni adaylarının uzaktan eğitime yönelik görüşleri [Turkish teacher candidates' views on distance education]. RumeliDE Dil ve Edebiyat Araştırmaları Dergisi, 19, 220-241. https://doi.org/10.29000/rumelide.752297

Kaya, A. B. (2019). Küreselleşme çağında yükseköğretimin yeniden yapılandırılması [Restructuring higher education in the age of globalization]. In C. Celep (Ed.), Karşılaştırmalı eğitim yönetimi (pp. 133-163). Hiperyayın.

Keskin, M., \& Kaya, D. Ö. (2020). Covid-19 sürecinde öğrencilerin web tabanlı uzaktan eğitime yönelik geri bildirimlerinin değerlendirilmesi [Evaluation of students' feedbacks on web-based distance education in the Covid-19 process]. İzmir Katip Çelebi Üniversitesi Să̆lık Bilimleri Fakültesi Dergisi, 5(2), 59-67. https://dergipark.org.tr/tr/pub/ikcusbfd/issue/55773/754174

Kırık, A. M. (2014). Uzaktan eğitimin tarihsel gelişimi ve Türkiye'deki durumu [Historical development of distance education and the situation in Turkey]. Marmara İletişim Dergisi, 21, 73-94.

Koç, E. S. (2021). Nasıl bir uzaktan eğitim? 1 yılın sonunda yapılan çalışmaların değerlendirilmesi [What kind of distance education? An evaluation of the studies done at the end of 1 year]. International Anatolia Academic Online Journal Social Sciences Journal, 7(2), 13-26. https://dergipark.org.tr/tr/pub/iaaoj/issue/60800/892227

Köroğlu, İ. S. (2021). Covid-19 sürecinde eğitim yoksulluğu [Educational poverty during the Covid-19]. International Journal of Economic and Adminıstratıve Academic Research, 1(2), 74-89. https://www.ijerdergisi.com/index.php/ijer/article/view/16/20

Lautenbach, G., \& Randell, N. (2020). Through the Covid-19 looking glass: Coping skills for STEM educators in the time of a pandemic and beyond. Journal of Baltic Science Education, 19(6A), 1068-1077. https://doi.org/10.33225/jbse/20.19.1068

Manuel, A., Buque, D., \& Quive, R. (2021). Students' perceptions on distance education: A case study in Mozambique. Problems of Education in the 21st Century, 79(2), 229-240. https://doi.org/10.33225/pec/21.79.229

Markovič Krstić, S. V., \& Miloševič Radulović, L. R. (2021). Evaluating distance education in Serbia during the Covid-19 pandemic. Problems of Education in the 21st Century, 79(3), 467-484. https://doi.org/10.33225/pec/21.79.467

Mellieon, H. I. Jr., \& Robinson, P. A. (2021). The new norm: Faculty perceptions of condensed online learning. American Journal of Distance Education, 35(3), 170-183. https://doi.org/10.1080/08923647.2020.1847626 
Miles, M. B., \& Huberman, A. M. (1994). Qualitative data analysis: An expanded sourcebook (2nd ed.). SAGE Publications.

Moore, M. G. (1973). Toward a theory of independent learning and teaching. The Journal of Higher Education, 44(9), 661-679. https://doi.org/10.2307/1980599

Naidu, S. (2021). Building resilience in education systems post-COVID-19. Distance Education, 42(1), 1-4. https://doi.org/10.1080/01587919.2021.1885092

Özbay, Ö. (2015). Dünya'da ve Türkiye'de uzaktan eğitimin güncel durumu [The current status of distance education in the world and Turkey]. Uluslararası Ĕgitim Bilimleri Dergisi, 2(5), 376394. https://dergipark.org.tr/tr/pub/inesj/issue/40015/475774

Özçelik, F. K. (2021). Covid-19 salgını sürecinde üniversite eğitiminde kullanılan uzaktan eğitim platformlarının 6698 sayılı kişisel verilerin korunması kanunu çerçevesinde değerlendirilmesi [The evaluation of distance education platforms used in university education during Covid-19 pandemic disease under the personal data protection law]. Süleyman Demirel Üniversitesi Hukuk Fakültesi Dergisi, 11(1), 135-170. https://doi.org/10.52273/sduhfd..928688

Özdoğan, A., \& Berkant, H. (2020). Covid-19 pandemi dönemindeki uzaktan eğitime ilişkin paydaş görüşlerinin incelenmesi [The examination of stakeholders' opinions on distance education during the Covid-19 epidemic]. Milli Eğitim Dergisi, Salgın Sürecinde Türkiye'de ve Dünyada Ĕ̆itim, 49(1), 13-43. https://doi.org/10.37669/milliegitim.788118

Raymond, F. B. (2005). The history of distance education in social work and the evolution of distance education modalities. In P. Abels (Ed.), Distance education in social work planning, teaching, and learning (pp. 23-40). Springer Publishing Company.

Sahranç, Ü. (2019a). Öğrenmeyi etkileyen etkenler [Factors affecting learning]. In İ. Yıldırım (Ed.), Eğitim psikolojisi (8th ed., pp. 363-386). Anı Yayıncılık.

Sahranç, Ü. (2019b). Temel öğrenme ortamları: Aile-okul-sınıf [Basic learning environments: Familyschool-classroom]. In İ. Yıldırım (Ed.), Eğitim psikolojisi (8th ed., pp. 333-362). Anı Yayıncılık.

Serçemeli, M., \& Kurnaz, E. (2020). Covid-19 pandemi döneminde öğrencilerin uzaktan eğitim ve uzaktan muhasebe eğitimine yönelik bakış açıları üzerine bir araştırma [A research on students' perspectives to distance education and distance accounting education in the Covid-19 pandemia period]. Uluslararası Sosyal Bilimler Akademik Araştırmalar Dergisi, 4(1), 40-53. https://dergipark.org.tr/tr/pub/utsobilder/issue/55152/741358

Shih, T. K., Hung, J. C., Ma, J., \& Jin, Q. (2007). A survey of distance education challenges and technologies. In T. K. Shih \& J. C. Hung (Eds.), Future directions in distance learning and communication technologies (pp. 1-25). IGI Global.

Simonson, M., Smaldino, S., \& Zvacek, S. (2015). Teaching and learning at a distance foundations of distance education (6th ed.). Information Age Publishing.

Şişman, M. (2020). Ě̆itime giriş [Introduction to education] (21st ed.). Pegem Akademi.

Türküresin, H. E. (2020). Covid-19 pandemi döneminde yürütülen uzaktan eğitim uygulamalarının öğretmen adaylarının görüşleri bağlamında incelenmesi [Examination of distance education practices conducted during the Covid-19 pandemic regarding the views of preservice teachers]. Milli Ĕ̌itim Dergisi, Salgın Sürecinde Türkiye'de ve Dünyada Eğitim, 49(1) 597618. https://doi.org/10.37669/milliegitim.787509

Uluöz, E. (2020). Opinions of the faculty of sport sciences students on the changes in education system during Covid-19 pandemic: A qualitative research. African Educational Research Journal, 8(3), 481-490. https://doi.org/10.30918/AERJ.83.20.114

Wedemeyer, C. A. (1981). Learning at the back door: Reflections on non-traditional learning in the lifespan. The University of Wisconsin Press.

Yamamoto, G. T., \& Altun, D. (2020). Coronavirüs ve çevrimiçi (online) eğitimin önlenemeyen yükselişi [The coronavirus and the rising of online education]. Üniversite Araştırmaları Dergisi, 3(1), 2534. https://doi.org/10.32329/uad.711110

Yeşilyaprak, B. (2020). Eğitim psikolojisi gelişim-öğrenme-öğretim [Educational psychology development-learning-teaching] (23rd ed.). Pegem Akademi.

Yıldırım, A., \& Şimşek, H. (2016). Sosyal bilimlerde nitel araştırma yöntemleri [Qualitative research methods in the social sciences] (10th ed.). Seçkin yayıncılık.

Yılmaz, A. B., \& Karataş, S. (2020). Açık ve uzaktan öğrenmenin temel kavramları, kuramları ve felsefesi [Basic concepts, theories and philosophy of open and distance learning]. In E. Tekinarslan \& M.D. Gürer (Eds.), Açık ve uzaktan öğrenme (3rd ed., pp. 1-28). Pegem Akademi. 
Uğur ÖZER. Evaluation of distance education process in sports higher education

PROBLEMS

OF EDUCATION

IN THE $21^{\text {st }}$ CENTURY

Vol. 80 , No. 1,2022

212

Yolcu, H. (2020). Koronavirüs (Covid-19) pandemi sürecinde sınıf öğretmeni adaylarının uzaktan eğitim deneyimleri [Preservice elementary teachers' distance education experiences at the time of Coronavirus (Covid-19) pandemic]. Açıköğretim Uygulamaları ve Araştırmaları Dergisi, 6(4), 237-250. https://dergipark.org.tr/tr/pub/auad/issue/57638/788890

Yurdakul, I. K. (2013). Evren ve örneklem [Universe and sample]. In A.A. Kurt (Ed.), Bilimsel araştırma yöntemleri (pp. 75-92). Anadolu Üniversitesi Açıköğretim Fakültesi Yayınları.

Received: November 19, 2021

Accepted: January 20, 2022

Cite as: Özer, U. (2022). Evaluation of distance education process in sports higher education. Problems of Education in the $21^{\text {st }}$ Century, 80(1), 195-212. https://doi.org/10.33225/pec/22.80.195

Uğur Özer

PhD, Assistant Professor, Department of Sport Management, Hitit University Vocational School of Social Sciences, Çorum-Turkey.

E-mail: ugurozer84@hotmail.com

Website: http://web.hitit.edu.tr/ugurozer

ORCID: https://orcid.org/0000-0002-3899-3429 